\title{
Aspek-Aspek dalam Menyusun Bahan Ajar Komsel: Suatu Usulan Bagi Gereja Penyebaran Injil Majalengka
}

\author{
Debi Debora Kusumawati \\ Sekolah Tinggi Teologi Kharisma Bandung \\ debi09430@gmail.com \\ Joko Prihanto \\ Sekolah Tinggi Teologi Kharisma Bandung \\ tugasjokopri@gmail.com
}

\begin{abstract}
Cell Group is a very basic form of ministry that must be developed by the church in helping the congregation it serves so that it becomes more mature and grows in the knowledge of God. In addition to praise, prayer, and worship, teaching is an important thing in the conduct of cell groups. In connection with teaching, the church must prepare teaching materials that are relevant to the needs of cell group members. The goal is to make the cell group members more interested in joining the cell group, and to become more mature in God and able to face the challenges of life that they are facing. The research method used is library research. This method collects data and information in the form of documents, data archives and other literature information. In addition, this study also uses the interview method. This paper is expected to provide an overview for churches in compiling teaching materials relevant to cell group members. This paper will discuss the nature of cell groups, the importance of teaching materials that are relevant to cell group members, the biblical basis on teaching materials relevant to cell group members, and ends with aspects in compiling teaching materials in cell groups, namely that cell groups teaching materials must easy to understand, cell group teaching materials must be in accordance with the spiritual level of cell group members, cell group teaching materials must focus on the Bible and discuss Bible themes, teaching materials must consider the psychological level of cell group members, teaching materials must focus on the life experiences of cell group members, teaching materials must be in accordance with the life struggles of cell group members.
\end{abstract}

Keywords: Church, Teaching material, Cell group

\begin{abstract}
Abstrak
Kelompok Sel (Komsel) merupakan salah satu bentuk pelayanan yang sangat mendasar yang harus dikembangkan oleh gereja dalam membantu jemaat yang dilayani supaya semakin dewasa dan semakin bertumbuh dalam pengenalan akan Tuhan. Selain pujian, doa, dan penyembahan maka pengajaran merupakan hal yang penting dalam pelaksanaan komsel. Sehubungan dengan adanya pengajaran, maka gereja harus menyiapkan bahan ajar yang relevan dengan kebutuhan anggota komsel. Tujuannya supaya anggota komsel semakin berminat dalam mengikuti komsel, serta semakin dewasa dalam Tuhan dan mampu menghadapi tantangan hidup yang sedang dihadapinya. Metode penelitian yang digunakan adalah penelitian pustaka. Metode ini mengumpulkan data dan informasi dalam bentuk
\end{abstract}


dokumen, arsip data maupun informasi literatur lainnya. Selain itu, penelitian ini juga menggunakan metode wawancara. Tulisan ini diharapkan dapat memberikan gambaran bagi gereja-gereja dalam menyusun bahan ajar ajar yang relevan dengan anggota komsel. Tulisan ini akan membahas mengenai hakikat komsel, pentingnya bahan ajar yang relevan dengan anggota komsel, dasar Alkitab mengenai bahan ajar yang relevan dengan anggota komsel, dan diakhiri dengan aspek-aspek dalam menyusun bahan ajar dalam komsel, yaitu bahan ajar komsel harus mudah dimengerti, bahan ajar komsel harus sesuai dengan tingkat kerohanian anggota komsel, bahan ajar komsel harus berfokus pada alkitab dan membahas tema-tema Alkitab, bahan ajar harus mempertimbangkan tingkat psikologi anggota komsel, bahan ajar harus berfokus pada pengalaman hidup anggota komsel, bahan ajar harus sesuai dengan pergumulan hidup anggota komsel.

Kata-kata kunci: Gereja, Bahan ajar, Komsel

\section{PENDAHULUAN}

Pelayanan Komsel merupakan salah satu terobosan yang dilakukan oleh gereja dalam mengembangkan pelayanan. Di abad ke dua puluh ini, fenomena pelayanan komsel semakin digalakkan oleh gerejagereja yang menginginkan terjadinya pertumbuhan iman bagi jemaat yang dilayani. Seperti yang dikemukakan oleh Ralph W. Neighbour bahwa, "Sejarah pertumbuhan gereja selalu diwarnai dengan banyak gerakan rohani yang terjadi dalam sejarah gereja. Salah satu fenomena gerakan rohani yang terjadi di antara gereja-gereja yang bertumbuh di seluruh dunia yang terjadi menjelang akhir abad dua puluh adalah gerakan kelompok sel. ${ }^{1}$

Gereja-gereja yang melakukan pemuridan melalui pelayanan komsel lebih

\footnotetext{
${ }^{1}$ Ralph W Neighbour, Where Do We Go from Here?: A Guidebook for the Cell Group Church (Houston, Tex.: Touch Publications, 2000), 23-24.
}

cenderung berkembang dibandingkan dengan gereja yang sama sekali tidak melakukan pelayanan komsel. Seperti yang dikemukakan oleh Sugihcahyono menyatakan bahwa: "Komsel yang menghasilkan pertumbuhan gereja yang dinamis telah menjadi suatu fenomena yang meliputi seluruh gereja di dunia. Gerejagereja yang paling cepat pertumbuhannya di dunia zaman ini adalah gereja-gereja yang sukses di dalam persekutuannya. ${ }^{2}$

Secara praktis dalam pelaksanaan komsel, selain doa, pujian dan penyembahan maka pengajaran juga merupakan salah satu aspek penting dalam mengembangkan komsel. Seperti yang dikemukakan Daniel Sutoyo bahwa, komsel adalah salah satu program gereja yang sangat efektif. Dalam komsel selain, doa dan penyembahan, maka pemuridan

\footnotetext{
2 Joni Sugicahyono, "Panduan Kelompok Kecil," Adoc.Pub, accessed August 14, 2021, https://adoc.pub/panduan-kelompok-kecil-subbidang-pembinaan-warga-gereja-sin.html.
} 
dan pengajaran merupakan unsur yang sangat penting di dalamnya. Sebab sesuai dengan istilahnya, komsel merupakan suatu sel yang merupakan bagian dari organ tubuh manusia. Meski sel itu sangat kecil, akan tetapi sel itu menggabungkan diri dengan sel-sel yang membentuk saraf-saraf dan organ-organ penting dalam tubuh manusia. Karena itu, aspek terpenting dalam pelayanan komsel adalah doa, pujian, penyembahan serta pengajaran dari bahan komsel yang sudah disiapkan. Komsel harus menjadi wadah bagi jemaat untuk dibina dan menerima pengajaran sehingga jemaat bertumbuh dan semakin dewasa dalam Tuhan. ${ }^{3}$

Sehubungan dengan adanya pengajaran dalam komsel, gereja harus menyiapkan bahan ajar untuk dibagikan maupun didiskusikan dalam komsel. Bahan ajar komsel yang disiapkan haruslah bahan ajar yang relevan dengan kebutuhan anggota komsel. Seperti yang dikemukakan oleh Easum dan Atkonson bahwa bahan ajar yang disajikan oleh gereja pada saat komsel adalah bahan ajar yang relevan dengan kebutuhan anggota komsel. Hal ini penting untuk meningkatkan minat serta motivasi anggota komsel untuk terus terlibat dalam komsel dan bahan ajar yang

\footnotetext{
${ }^{3}$ Daniel Sutoyo, "Komunitas Kelompok Kecil Sebagai Tempat Pembelajaran Gaya Hidup Kristen," Jurnal Antusias, STT. Intheos 2, No 2 (2012): 4.

4 Bill Eausum and Jhon Atkinson, 11
}

relevan dengan kebutuhan anggota komsel akan menolong anggota komsel semakin dewasa, mengenal Tuhan dan mampu menghadapi tantangan hidup yang sedang terjadi. ${ }^{4}$ Widjaja juga berpendapat bahwa dalam komsel jemaat bisa dibina dan diajar untuk bertumbuh dan dewasa dalam Tuhan serta mampu menghadapi tantangan hidup melalui bahan pengajaran yang sudah disiapkan oleh gereja. ${ }^{5}$

Di Gereja Penyebaran Injil Majalengka penulis menemukan informasi bahwa bahan ajar komsel masih belum relevan dengan kebutuhan anggota komsel. Berdasarkan sumber yang diperoleh penulis pada hari Kamis, 1 Juli 2021, pukul 15.00 Wib pembicaraan melalui sambungan telepon dengan seorang anggota komsel di Gereja Penyebaran Injil Majalengka bernama Bapak Agus menyatakan bahwa bahan ajar komsel menggunakan bahasa yang sulit dimengerti, sehingga membuatnya kurang berminat untuk hadir dalam komsel.

Demikian juga pada hari Jumat, 2 Juli 2021, pukul 18.30 Wib pembicaraan melalui telepon engan seorang anggota komsel di Gereja Penyebaran Injil Majalengka bernama ibu Suryani menyatakan bahwa bahan ajar komsel yang

Langkah Meledakkan Kelompok Sel (Surabaya: Gandum Mas, 2016), 84.

${ }^{5}$ Imron Widjaja, "Perkembangan Komsel Pelajar Dalam Pertumbuhan Rohani Jemaat GBI GRAHA PENA JAKARTA” 5, no. 2 (2019): 88. 
diterimanya tidak menjawab pergumulan yang sedang dihadapinya, membuatnya merasa tidak puas dalam mengikuti komsel.

Selain itu, penulis juga menemukan informasi berdasarkan wawancara lewat telepon pada hari Jumat 2 Juli 2021 pukul 19.30 Wib dengan bapak Marzuki, anggota komsel Gereja Penyebaran Injil Majalengka menyatakan bahwa bahan ajar komsel tidak relevan dengan kerohaniannya. Sebab ia baru saja bergabung empat bulan dalam komsel tetapi sudah membahas materi akhir zaman yang menurutnya terlalu berat untuk dipelajari.

Selain informasi dari anggota komsel tersebut, gembala Gereja Penyebaran Injil Majalengka juga mengakui bahwa memang dalam menyusun materi komsel mereka belum tahu aspekaspek yang harus dipertimbangkan dalam menyusun bahan ajar komsel yang relevan dengan kebutuhan anggota komsel.

Karena itu, berdasarkan uraian di atas, maka fokus penelitian ini adalah mengapa penting bahan ajar komsel relevan dengan kebutuhan anggota komsel? Apa infomasi Alkitab tentang bahan ajar yang relevan dengan kebutuhan jemaat? Pada akhirnya, penulis akan menguraikan

\footnotetext{
${ }^{6}$ Ika Widyasari Simanjuntak and Talizaro Tafonao, "Urgenitas Dalam Menerapkan Kurikulum Pendidikan Agama Kristen Bagi Orang Dewasa Di Gereja" 1 (2021): 90.

${ }^{7}$ Eli Zaluchu Sonny, "Strategi Penelitian
}

tentang, apa aspek-aspek dalam menyusun bahan ajar yang relevan dengan anggota komsel?

Dengan demikian, tujuan penelitian ini adalah menolong Gereja Penyebaran Injil di Majalengka maupun gereja-gereja yang melaksanakan komsel supaya dalam menyusun bahan ajar komsel mempertimbangkan aspek-aspek yang akan diuraikan dalam penelitian ini.

\section{METODE PENELITIAN}

Metode penelitian yang digunakan adalah penelitian pustaka (librabry research atau telaah literature) Metode ini mengumpulkan data dan informasi dalam bentuk dokumen, arsip data maupun informasi literatur lainnya. ${ }^{6}$ Kemudian penulis akan melakukan pendekatan deskriptif. $^{7}$ Dengan tujuan untuk menjabarkan informasi yang penulis termukan sesuai dengan topik penelitian. Proses analisis yang dilakukan adalah menggunakan berbagai sumber literaturliteratur baik jurnal, buku dan bahan referensi lain yang terpercaya untuk mendukung analisis penulis terhadap topik penelitian. Selain itu, dalam penelitian ini, penulis juga menggunakan metode

Kualitatif Dan Kuantitatif Di Dalam Penelitian Agama," StrategiPenelitian Kualitatif dan Kuantitatif di dalam Penelitian Agama”, Evangelikal: Jurnal TeologiInjili dan Pembinaan Warga Jemaat 1 (2020): 23-28. 
wawancara.

\section{HASIL DAN PEMBAHASAN}

\section{Hakikat Komsel}

Berbeda gereja maka berbeda pula istilah yang digunakan untuk komsel. Namun perbedaan istilah tersebut memiliki makna yang sama. Seperti yang dikemukakan oleh Daniel Sutoyo bahwa: Ada berbagai macam istilah dipakai oleh gereja dengan maksud sama. Sama dengan Komsel, Gereja Sel, Home Family, Perek (Persekutuan Antar Keluarga, Loving Group, Kelompok Keluarga, Keluarga Melayani Sesama (Kemas), Kelompok Tumbuh Bersama (KTB), Pendalam Alkitab (PA), Family Altar (FA), Comunity Of Love (COOL), dan sebagainya. Secara umum defenisi Komsel atau adalah suatu komunitas kecil yang terdiri dari orangorang Kristen yang ingin saling mendukung untuk bertumbuh dalam Kristus. Komsel atau mengadakan pertemuan seminggu sekali untuk saling membangun antara anggota yang satu dengan anggota yang lain sebagai anggota tubuh Kristus. ${ }^{8}$

Echols dan Hasan Shadily menyatakan bahwa, "Komsel dalam bahasa inggris dipakai kata group, yang berarti

\footnotetext{
8 Sutoyo, "Komunitas Kelompok Kecil Sebagai Tempat Pembelajaran Gaya Hidup Kristen," 6.

9 Echols and Hasan Shadily, Kamus Inggris - Indonesia (Jakarta: PT. Gramedia, 1996),
}

kelompok, golongan atau golongangolongan yang membagi-bagi atas kelompok. ${ }^{9} \quad$ Sama seperti sel yang merupakan bagian yang sangat penting dalam tubuh makluk hidup, demikianlah digambarkan bahwa komsel juga merupakan bagian yang sangat penting dalam pelayanan gereja untuk membangun pertumbuhan gereja baik secara kualitas maupun kuantitas.

Seperti yang kemukakan Tjung bahwa: Komsel adalah singkatan dari komunitas sel. Jika kita pernah mempelajari biologi, sel adalah bagian terkecil dari tubuh kita. Sel membentuk jaringan. Jaringan membentuk organ. Organ membentuk sistem organ. Sistem organ membentuk organisme. Jadi tanpa sel maka kita tidak akan hidup. Begitu juga dengan komsel. Kita digambarkan sebagai anggota tubuh Kristus yang membentuk satu kesatuan menjadi sebuah gereja. Anggota tubuh memerlukan sel untuk bisa bertumbuh. Jadi tanpa sebuah komunitas sel, maka gereja tidak akan bisa bertumbuh dengan baik. Oleh karena itu tanpa sebuah komsel, maka gereja bisa dikatakan mati. ${ }^{10}$ Terkait dengan jumlah anggota kelompok dalam satu komsel, Sutoyo berpendapat bahwa, "komsel adalah

281.

10 Tjung Hanson, "Kenapa Harus
Komsel?," accessed August 14, 2021,
https://hansontjung.com/2018/09/13/kenapa-harus-
komsel/.


persekutuan antara saudara seiman dalam satu kelompok yang terdiri dari 3-12 orang atau sesuai dengan kebijakan masingmasing gereja lokal, yang digerakkan oleh semangat "saling memperhatikan/caring." Kehidupan yang saling memperhatikan ini menjadikan komsel suatu persekutuan yang indah, diwujudkan dalam kehidupan yang saling mengasihi, saling mendoakan dan bertumbuh bersama dalam kebenaran firman Tuhan. Tidak hanya di antara sesama anggota, tindakan "caring" juga dilakukan terhadap "orang luar," yaitu masyarakat sekitar lingkungan itu. Dengan demikian, anggota komsel menjadi saksi Kristus bagi dunia dan kehidupannya memancarkan terang kemuliaan Allah di tengah-tengah kegelapan dunia. ${ }^{11}$

\section{Pentingnya Bahan Ajar yang Relevan Terhadap Kebutuhan Anggota Komsel}

Dalam menyusun bahan ajar maka salah satu aspek penting yang menjadi pertimbangan adalah bahan ajar yang disusun harus relevan dengan kebutuhan anggota komsel. Seperti yang dikemukakan oleh Pazmino bahwa, "dalam menyusun bahan ajar salah satu pertanyaan penting yang harus dijawab ialah apakah bahan

\footnotetext{
Sugicahyono, "PANDUAN KELOMPOK KECIL."

12 Robert W. Pazmiño, Foundational Issues in Christian Education: An Introduction in Evangelical Perspective (Grand Rapids, Mich: Baker Book House, 1988), 327.
}

pelajaran yang disusun relevan dengan kehidupan mereka yang diajar?"12 Hal ini penting, supaya bahan ajar yang diajarkan dalam komsel membuat jemaat tetap tertarik untuk mengikuti komsel. Seperti yang dikemukakan Gladen bahwa: "Salah satu cara signifikan untuk membuat anggota kelompok tetap tertarik untuk mengikuti komsel adalah dengan membuat bahan ajar atau materi alam komsel bervariasi sesuai dengan kebutuhan anggota komsel."13

Selain itu, sesuai dengan apa yang dikemukakan oleh Donahue bahwa, "Pentingnya bahan ajar yang dirumuskan dalam komsel relevan dengan kebutuhan anggota komsel supaya tujuan yang ditetapkan dalam komsel dapat tercapai. Tujuan yang dimaksud adalah supaya anggota komsel mengalami pertumbuhan, kedewasaan dan mengalami kebenaran firman Tuhan dalam mennghadapi pergumulan kehidupan mereka seharihari." ${ }^{14}$ Sedangkan menurut Tim Perkantas bahwa: "Pentingnya bahan ajar yang relevan bagi anggota komsel adalah untuk kepentingan pribadi-pribadi anggota komsel dari lahir baru hingga menjadi murid Kristus yang dapat menjangkau

\footnotetext{
13 Steve Gladen, Memimpin Kelompok Kecil Dengan Tujuan (Yogyakarta: Yayasan Gloria, 2015), 144.

${ }^{14}$ Bill Donahue, Membimbing Kelompok Kecil Untuk Mengubah Hidup (Yogyakarta: Gloria Graffa, 2010), 116.
} 
orang lain serta menjadi garam dan terang dunia." 15

Jadi berdasarkan uraian di atas, maka bahan ajar komsel yang dirumuskan oleh gereja harus releven dengan kebutuhan jemaat. Hal ini penting supaya anggota komsel memiliki motivasi yang kuat untuk terus mengikuti komsel. Jikalau mereka telah tertarik untuk mengikuti komsel maka tanpa ada dorong atau paksaan dari gereja atau sesama anggota jemaat, mereka dengan sendirinya akan ikut komsel karena mereka dengan bahan ajar yang disampaikan dalam komsel. Selain itu, bahan ajar harus relevan dengan kebutuhan anggota komsel demi mencapai tujuan yang ditetapkan dalam membentuk komsel. Maksudnya ialah dengan bahan ajar yang disampaikan dalam komsel maka anggota komsel akan mengalami pertumbuhan dan kedewasaan rohani. Serta melalui bahan yang disampaikan anggota komsel cakap ntuk menghadapi pergumulan mereka sehari-hari dengan mengandalkan firman Tuhan.

Hal penting lainnya adalah dengan bahan komsel yang relevan dengan kebutuhan anggota komsel maka jemaat dibimbing mulai dari lahir baru, yaitu percaya dan menerima Tuhan Yesus, hingga mereka menjadi serupa dengan

15 Tim Staf Perkantas, Pemuridan dinamis membangun bangsa: memuridkan berbasis kelompok kecil dan profil, 2013, 37.
Kristus. Melalui hal tersebut, maka anggota komsel akan mampu untuk menjadi garam dan terang bagi orang lain serta mampu untuk bersaksi dan memberitakan Injil.

\section{Dasar Alkitab Mengenai Bahan Ajar Yang Relevan Terhadap Kebutuhan Jemaat}

Pada bagian berikut penulis akan membahas landasan Alkitab mengenai bahan ajar yang relevan dengan kebutuhan jemaat. Dalam hal ini penulis akan menyoroti kitab Kolose. Daud Darmadi berpendapat bahwa, berdasarkan Surat Kolose, dapat dilihat bahwa Paulus sendirilah yang menjadi penulisnya (1:1,23; 4:18). Paulus mengidentifikasi dirinya sebagai seorang rasul dan seorang pelayan. Ia mengakhiri surat Kolose dengan gayanya yang khas, yaitu salam yang ditulis dengan tangannya sendiri. ${ }^{16}$

Adapun yang melatarbelakangi Paulus menulis surat kepada jemaat di Kolose adalah masuknya sekelompok guruguru palsu yang menyusup ke dalam jemaat dan menyebarkan ajaran yang mengancam iman umat. Mereka mengajarkan filsafat yang menurut Paulus filsafat kosong. Filsafat kosong yang dimasuk ialah pengajaran yang berkaitan dengan tradisitradisi sekaligus ritus-ritus, dan

${ }^{16}$ Daud Darmadi, "Makna Kolose 2:6-7 Dalam Pertumbuhan Rohani Jemaat Masa Kini" 1, no. 2 (2019): 6. 
pengetahuan yang diwahyukan. ${ }^{17}$

Sementara Drane menyatakan bahwa, kesesatan jemaat di Kolose karena adanya keyakinan bahwa keselamatan lengkap dan langgeng yang mereka peroleh tidak dapat dicapai hanya dengan iman kepada Yesus saja, tetapi perlu ditambah dengan pengertian mengenai soal-soal ilahi melalui pengetahuan rahasia yang diberikan dengan cara mistik (Kol. 2:23). Pengetahuan seperti itu dapat diperoleh dengan mengambil bagian dalam berbagai praktek upacara agama seperti sunat, tidak makan-makanan tertentu, dan memelihara hari-hari raya Yahudi dan hari Sabat. ${ }^{18}$

Berdasarkan uraian di atas, pengaruh pengajaran tardisi Yahudi dan filsafat Yunani membuat iman jemaat di Kolose membuat menyimpang dari iman yang sebenarnya yang berpusat kepada Tuhan Yesus Kristus. Iman jemaat di Kolose telah dipengaruhi oleh hal-hal mistis dan keharusan untuk melakukan halhal lahiriah. Jemaat di Kolose diajar untuk memperoleh keselamatan maka mereka selain percaya kepada Tuhan Yesus maka harus melakukan ritual-ritual agama yang dipengaruhi oleh agama Yahudi.

Untuk itu, pengajaran yang relevan dengan kebutuhan jemaat di Kolose ada

17 Benyamin Samuel Hakh, Perjanjian Baru (Bandung: Bina Media Informasi, 2010), 215.

18 Drane and Katoppo, Memahami Perjanjian Baru, 318. pengajaran yang dapat menjelaskan tentang keunggulan Yesus Kristus yang adalah Allah yang berinkarnasi menjadi manusia. Seperti yang dinyatakan oleh Subandrijo bahwa: Dalam surat Paulus dalam surat Kolose mengajarkan kristologi tinggi atau kristologi dari atas, yang menekankan keutamaan Kristus, baik atas mahlukmahluk lain maupun atas ciptaan-Nya sendiri. Kristologi dari atas bertolak dari keilahian Kristus yang di dalamnya konsep inkarnasi merupakan pusatnya."19

Melalui surat Kolose, rasul Paulus ingin mengajarkan tentang keunggulan Yesus Kristus kepada jemaat di Kolose untuk menolong mereka memahami pemahaman yang benar tentang Yesus Kristus sehingga dibersihkan dari pengajaran filsafat kosong yang telah menawan pikiran mereka. Seperti yang dikemukakan Chapman bahwa: Paulus menjelaskan pokok doktrin mengenai keunggulan Yesus Kristus seperti berikut: Satu, dalam ke-Allahan-Nya, Yesus Kristus merupakan yang sulung, dan gambar Allah Bapa yang tidak kelihatan (Kol. 1:15). Dua, sebagai pencipta, Yesus Kristus menjadikan dengan firman-Nya apa yang tidak ada menjadi ADA. Segala sesuatu dijadikan oleh Dia dan untuk Dia, yaitu

${ }^{19}$ Subandrijo, Perjanjian Baru 1 (Bandung: Bina Media Informasi, 2010), 158. 
untuk kemuliaan-Nya (Kol. 1:16). Tiga, Kristus ada dari kekal (Kol. 1:17). Empat, Kristus dinyatakan sebagai Kepala Jemaat. Dialah yang lebih utama dalam segala sesuatu (Kol. 1:18). Dalam Dialah, sebagai Kepala, segala sesuatu ditunjang dan diikat menjadi satu agar semua anggota tubuhNya bertumbuh dalam sikap keilahian-Nya (Kol. 2:19). Lima, seluruh kepenuhan Allah diam di dalam Dia (Kol. 1:19 dan 2:9-10), yaitu dalam kesucian-Nya, kemahakuasaan-Nya, kemahatahuan-Nya, kemahakasih-Nya, kemuliaan-Nya dan sebagainya. Enam, Kristus memperdamaikan segala sesuatu dengan diri-Nya (Ko. 1:20). ${ }^{20}$

Stephanus juga menyatakan hal yang sama bahwa, melalui surat Kolose, Paulus ingin mengajarkan Injil yang benar dalam Tuhan Yesus, sehingga jemaat bisa mengalami pertumbuhan pengenalan akan Tuhan Yesus dan dihindarkan dari pengajaran sesat yang muncul pada waktu itu. $^{21}$

Dengan belajar kepada surat yang ditulis oleh Paulus kepada jemaat di Kolose maka penulis menemukan bahwa bahan pengajaran harus dibuat oleh gereja kepada jemaat meliputi hal berikut:

Satu, bahan yang menambah pengetahuan Alkitab kepada jemaat. Gereja

\footnotetext{
${ }^{20}$ Adina Chapman, Pengantar Perjanjian Baru (Bandung: Kalam Hidup, 2019), 130-131.

21 Stepanus, "Keunggulan Yesus Kristus
}

harus mengetahui perkembangan pengetahuan jemaat tentang kebenaran firman Tuhan. Apalagi ditengah-tengah kemajuan teknologi dan media sekarang ini, banyak sumber yang bisa dipakai jemaat untuk memperoleh pengetahuan akan Alkitab, seperti internet, youtobe, dll. Karena itu, gereja harus mengetahui apakah infomasi dan pengetahuan jemaat tentang pemahaman Alkitab yang diperoleh sendiri dari berbagai media masih benar atau justru sebaliknya telah membuat jemaat menyimpang dari kebenaran Alkitab.

Kedua, bahan yang menjawab pergumulan kerohanian jemaat. Gereja harus tahu sejauh mana perkembangan kerohanian jemaat. Apakah jemaat sudah dewasa secara rohani atau belum. Dengan mengetahui kondisi yang demikian maka gereja mudah untuk menyusun bahan yang sesuai dengan kondisi jemaat. Sama seperti jemaat di Kolose jemaat yang belum dewasa secara rohani sehingga mudah dipengaruhi dan disusupi oleh pengajaran yang sesat.

Ketiga, bahan yang berfokus kepada pengenalan akan Tuhan Yesus. Gereja harus menyusun bahan ajarnya dengan bahan yang berfokus kepada Tuhan Yesus. Hal ini penting karena pengajaran yang bepusat kepada Yesus Kristus merupakan

Menurut Kolose 1:16-18," HUPERETES: Jurnal Teologi dan Pendidikan Kristen 1, no. 1 (December 14, 2019): 50. 
fondasi yang kuat dan teguh bagi iman jemaat. Dengan bahan yang berfokus kepada Kristus maka jemaat dimampukan untuk menghadapi pengajaran sesat dan mampu menghadapi tantangan hidup.

\section{Aspek-Aspek Dalam Menyusun Bahan Ajar yang Relevan Terhadap Anggota Komsel}

Dalam menyusun bahan ajar bagi jemaat dalam hal ini melalui komsel maka hal yang harus menjadi pertimbangan ialah bahan tersebut harus relevan dengan kebutuhan jemaat. Adapun aspek-aspek yang penting dalam menyusun bahan ajar yang relevan terhadap kebutuhan anggota komsel harus meliputi hal berikut, yakni:

\section{Bahan Ajar Harus Mudah Dimengerti}

Berbeda anggota komsel maka berbeda pula tingkat pengetahuan dan latar belakang pendidikan mereka. Karena itu, bahan ajar komsel yang disusun haruslah bahan ajar yang mudah dimengerti dan dipahami oleh setiap anggota komsel sesuai dengan kemampuan mereka untuk menelaah dan memahami bahan tersebut. Garisson menyatakan bahwa: Salah satu ciri bahan ajar yang relevan dengan kebutuhan anggota komsel adalah bahan ajar yang disajikan dan disampaikan dalam pertemuan merupakan bahan yang mudah

22 Alton Garisson, Pemuridan Yang Berhasil: Murid 360 (Surabaya: Gandum Mas, dicerna dan dipahami oleh anggota komsel. Hal ini penting supaya anggota komsel bisa menerima dan berinteraksi dengan bahan komsel yang dibagikan. ${ }^{22}$

Karena itu, penulisan dan gaya bahasa yang dipakai dalam menyusun bahan komsel harus disesuaikan dengan pengetahuan dan pemahaman anggota komsel. Selain itu, pemimpin komsel yang bertindak membagikan bahan komsel harus menggunakan bahasa yang mudah dimengerti sesuai dengan latar belakang pendidikan anggota komsel yang dilayani.

\section{Bahan Ajar Harus Sesuai Dengan Tingkat Kerohanian Anggota Komsel}

Dalam menyusun bahan komsel, maka gereja harus memperhatikan tingkat kerohanian anggota komsel yang dilayaninya. Hal ini sesuai dengan uraian yang disampaikan oleh Gladen bahwa: Bahan yang diajarkan dalam komsel haruslah bahan yang relevan dengan kebutuhan jemaat karena itu sangat penting untuk memperhatikan tingkat kerohanian jemaat. Untuk mengetahui tingkat kerohanian jemaat maka pemimpin komsel harus mengenali setiap jemaat sehingga bahan akan dipersiapakan akan mendorong anggota komsel mengambil langkah kerohanian berikutnya. ${ }^{23}$

2016), 56.

23 Gladen, Memimpin Kelompok Kecil 
Berbeda anggota komsel maka berbeda pula tingkat kerohanian mereka. Apalagi anggota komsel yang baru bergabung tentu memiliki kerohanian yang lebih rendah dibandingkan dengan anggota komsel yang lebih lama bergabung. Barker, dkk, berpendapat bahwa: Bagi mereka yang baru percaya fokus bahan pelajaran dalam komsel harus menanamkan fondasi iman yang kokoh dalam Kristus. Sedangkan bagi mereka yang sudah dewasa rohani maka bahan pelajaran yang disiapkan harus mendorong jemaat untuk menemukan, mengembangkan dan menggunakan karunia-karunia rohani dalam melayani dan mendorong anggota komsel untuk memberitakan Injil. ${ }^{24}$

Karena itu, penting bagi pemimpin komsel untuk mengenal tingkat kerohanian setiap anggota komsel yang dilayaninya. Seperti yang dikemukakan oleh Barker bahwa: Untuk menjawab kebutuhan jemaat anggota komsel, maka pemimpin komsel harus mengenal anggota komsel yang dilayaninya karena itu pemimpin komsel harus membangun relasi dengan jemaat supaya dengan demikian terjalin kepercayaan dan saling mengenal dengan baik. $^{25}$

Untuk itu, gereja harus membuat klasifikasi anggota komsel berdasarkan

Dengan Tujuan, 138.

24 Steve Barker et al., Pemimpin Kelompok Kecil (Jakarta: PERKANTAS, 1996), 94 tingkat kerohanian mereka kemudian menyiapkan bahan ajar yang relevan dengan tingkat pertumbuhan iman mereka. Dengan demikian maka bahan ajar yang disampaikan sesuai dengan tahap pertumbuhan iman jemaat.

Bahan Ajar Komsel Harus Berfokus Pada Alkitab dan Membahas Tema-Tema Alkitab

Dalam merumuskan bahan ajar komsel maka aspek yang terpenting yang harus dipertimbangkan ialah bahan ajar tersebut harus memiliki dasar Alkitab yang kuat. Hal ini sesuai dengan gagasan yang dikemukakan oleh Galden bahwa: Bahan yang sesuai dengan kehidupan anggota komsel adalah bahan yang berfokus kepada Alkitab. Sasaran dalam dalam pembelajaran komsel harus mengenalkan Firman dan kebenaran Tuhan dalam hidup anggota komsel yang duduk secara bersamaan dalam menerima pengajaran. Bahan ajar komsel yang disiapkan juga harus memiliki kebenaran yang kuat baik dari sudut pandang Perjanjian Lama dan Perjanjian Baru. Bahan ajar komsel harus disusun dengan mempertimbangkan hubungan atau kesinambungan materi antara Perjanjian Lama dengan Perjanjian Baru. Selain itu, dalam menyiapkan bahan

103.

$$
{ }^{25} \text { Ibid., 91-92. }
$$


ajar komsel harus menguraikan berbagai tema-tema pokok Alkitab seperti mengenal Allah, Keselamatan, Dosa, Gereja, Akhir Zaman, dll. ${ }^{26}$

Hal yang sama juga disampaikan oleh Purim Marbun bahwa, bahan ajar bagi warga jemaat harus selalu berfokus pada Alkitab atau firman Tuhan. Beberapa alasan mendasar mengapa gereja mendasarkan bahan ajar pembinaan dengan Alkitab, yakni: pertama, pengertian dan pemahaman tentang hal-hal rohani tidak ditemukan dalam buku mana pun selain dari Alkitab. Karena Alkitab secara fundamental memberikan tatanan dan nilainilai rohani. Kedua, firman Tuhan adalah berita utama yang sangat relevan dan signifikan untuk pembinaan kerohanian. Salah satu implikasi pembinaan bermuara kepada karakter yang dimiliki jemaatjemaat. Jika berita utama firman Tuhan disampaikan melalui pembinaan rohani, niscaya karakter jemaat akan terbangun dengan baik. Ketiga, pembinaan rohani mengisyaratkan hal-hal yang menyentuh spiritualitas. $^{27}$

Ely Tanya juga menyatakan hal yang sama bahwa: "Bahan ajar bagi warga

${ }^{26}$ Ibid., 139.

27 Purim Marbun, "Strategi dan Model Pembinaan Rohani untuk Pendewasaan Iman Jemaat," Jurnal Ilmiah Religiosity Entity Humanity (JIREH) 2, no. 2 (December 23, 2020): 154.

28 Eli Tanya, Gereja Dan Pendidikan Agama Kristen: Mencermati Peranan Pedagogis Gereja (Cipanas: Sekolah Tinggi Teologi Cipanas, jemaat harus berfokus pada Alkitab serta membahas tema-tema Alkitab seperti keselamatan, mengenal Allah, gereja, d1l." ${ }^{28}$ Sidjabat juga menambahkan bahwa: "Warga jemaat harus belajar pengetahuan iman Kristen seperti Tritunggal, keselamatan, manusia dan dosa, dll." ${ }^{29}$

Dengan demikian, maka salah satu aspek yang terpenting yang harus menjadi dasar pertimbangan dalam menyusun bahan ajar komsel adalah bahan ajar tersebut harus memiliki dasar atau fondasi Alkitab yang kuat baik dari Perjanjian Lama maupun Perjanjian Baru. Materi komsel juga harus dilihat dari kesinambungan antara Perjanjian Lama dan Perjanjian Baru. Selain itu, dalam menyusun bahan ajar komsel harus menyertakan tema-tema Alkitab seperti tema Tritunggal, Dosa, Keselamatan, Baptisan, Penginjilan, Akhir jaman, dll.

Bahan Ajar Harus Mempertimbangkan Tingkat Psikologi Anggota Komsel

Berbeda usia maka berbeda pula tingkat psikologi dan kebutuhan serta pergumulan yang mereka hadapi ${ }^{30}$ Johanes W Hasugian juga menyatakan bahwa,

2006), 33-34.

${ }^{29}$ B.S Sidjabat, Pendewasaan Manusia Dewasa (Bandung: Kalam Hidup, 2014), 14.

${ }^{30}$ Rita evimalinda, "Konsep Kurikulum Pembinaan Warga Gereja Khususnya Remaja," REAL DIDACHE. Jurnal STT REAL BATAM 3 No 1 (Maret, 2018): 40. 
setiap masa atau tahap perkembangan kehidupan manusia memiliki kebutuhannya masing-masing, yang harus dipenuhi. Pemenuhan kebutuhan itu merupakan hal yang mendasar bagi setiap individu sehingga mereka dapat melaksanakan perannya sesuai dengan tahap perkembangannya masing-masing. ${ }^{31}$

Karena itu, dalam menyusun bahan komsel, maka gereja harus memperhatikan tingkat psikologi anggota komsel yang dilayani. Seperti yang dikemukakan oleh Andar Ismail bahwa, Prinsip utama untuk membuat bahan ajar bagi warga jemaat adalah selain mengenal mereka berdasarkan tingkat kerohanian, penting juga memperhatikan tingkat psikologi mereka berdasarkan usia dan jenis kelamin mereka. ${ }^{32}$ Sidjabat mengemukakan bahwa: "Berbeda usia pelajar maka berbeda pula kebutuhan sesuai dengan tingkat perkembangannya." 33

Lebih lanjut, Sidjabat mengemukakan bahwa: Pemuda dan usia dewasa awal lazimnya mereka yang berusia 18-22 tahun. Adapun tugas dan tanggung jawab mereka pada usia ini diantaranya: Satu, membenahi kemandirian karena lepas dari otoritas orangtua. Dua, membangun

\footnotetext{
${ }^{31}$ Johanes Waldes Hasugian, "Kurikulum dan Pembelajaran Warga Jemaat Dewasa di Gereja" (2019): 38.

32 Andar Ismail, Selamat Sejahtera: 33 Renungan Tentang Kedamaian (Jakarta: BPK Gunung Mulia, 2002), 50.
}

karier di tempat kerja atau belajar. Tiga, mengelola keuangan dengan bijak. Empat, membangun persahabatan. Lima, membangun kemesraan dengan kekasih. Enam, menikah serta membangun keluarga. Tugas-tugas perkembangan itu membawa pengaruh terhadap cara beriman mereka. ${ }^{34}$ Sedangkan untuk mereka yang sudah dewasa menengah dan lanjut usia, Sidjabat menyatakan bahwa: "Sebutan dewasa menengah (usia tengah baya) biasanya ditujukan kepada mereka yang berusia sekitar 35-55 tahun. Adapun mereka yang berusia 55-65 tahun disebut memasuki tahap dewasa menengah akhir. ${ }^{35}$ Sidjabat melanjutkan bahwa: Di atas usia itu orang memasuki masa lanjut usia (lansia) atau juga disebut "masa usia indah". Pada usia pertengahan (35-55 tahun) banyak orang mengevalusi perjalanan hidup dan memaknainya (refleksi). Ada juga yang kecewa dengan perjalanan pada masa lalunya karena belum dapat mewujudkan impian, dan akibatnya mempersalahkan situasi, pasangan, anak, diri sendiri, bahkan Tuhan. Beban terbesar mereka adalah pendampingan anak, disamping tanggung jawab terhadap orangtua dan keluarga asal. Bagi yang

33 B.S Sidjabat, Mengajar Secara Profesional, 3rd ed. (Bandung: Kalam Hidup, 2017), 139.

\footnotetext{
${ }^{34}$ Ibid., 150

35 Ibid., 151.
} 
berusia 55 tahun bergumul dengan bagaimana menjalani masa pensiun secara efisien dan efektif. Mereka harus menyesuaikan diri dengan penghasilan (gaji) pensiun. Berjuang mencari kegiatan baru untuk memenuhi kebutuhan ekonomi. Bagi mereka yang lanjut usia (di atas 65 tahun) bergumul tentang gangguan kesehatan, perasaan terasing dan kesepian. Selain itu, pergumulan menghadapi kematian. ${ }^{36}$ Dengan demikian, berbeda usia anggota komsel maka berbeda pula kebutuhan sesuai dengan tingkat perkembangannya. Selanjutnya setelah mengetahui kebutuhan yang sesuai dengan perkembangan anggota komsel, maka akan sangat menolong bagi gereja dalam merumuskan bahan yang relevan dengan kebutuhan mereka.

Bahan Ajar Harus Sesuai Dengan Pergumulan Hidup Anggota Komsel

Setiap anggota komsel pasti memiliki pergumulan hidup yang berbedabeda. Harapannya, melalui kehadirannya dalam komsel, jemaat pasti berharap supaya mereka bisa menemukan jawaban atas pergumulan yang mereka hadapi. Karena itu, salah satu pertimbangan berikutnya yang harus dipikirkan oleh gereja dalam menyusun bahan ajar ialah bahan ajar tersebut harus sesuai dengan

\footnotetext{
${ }^{36}$ Ibid., 134-135.

37 Garisson, Pemuridan Yang Berhasil:
}

pergumulan hidup anggota komsel. Garisson berpendapat bahwa, dalam mempersiapkan dan mengembangkan bahan ajar bagi jemaat maka gereja harus menyiapkan bahan ajar yang sanggup menjawab pergumulan hidup jemaat. ${ }^{37}$

Ada anggota komsel yang bergumul tentang keuangan, pendidikan, ekonomi, membesarkan anak, kepahitan, dll. Karena itu, dalam menyiapkan bahan ajar komsel, gereja harus menyiapkan materi dari Alkitab yang sanggup menjawab pergumulan anggota komsel sehingga kehadiran mereka dalam komsel menjadi bermakna. Jika anggota komsel menemukan jawaban atas pergumulannya dalam komsel maka hal tersebut akan mendorong mereka untuk bersaksi sehingga menarik jemaat lainnya atau mereka yang baru percaya untuk bergabung dalam komsel.

Bahan Ajar Harus Berfokus Pada Pengalaman Hidup Anggota Komsel

Bahan yang relevan dengan kebutuhan anggota bukan saja bahan yang sudah disiapkan oleh gereja. Tetapi dalam pertemuan komsel pengalaman hidup sehari-hari anggota komsel dengan Tuhan, juga dapat dijadikan bahan pelajaran dengan cara membagikan pengalaman tersebut sehingga dapat menjadi sumber

Murid 360, 56. 
pembelajaran dan motivasi bagi anggota komsel lainnya. Seperti yang dikemukakan oleh Easum dan Antikson menambahkan bahwa: Dalam komsel pengalaman hidup anggota komsel bersama dengan Tuhan, dapat dijadikan menjadi sumber pembelajaran dalam komsel. Setiap anggota komsel yang memiliki kesaksian yang baik dan menang dalam menghadapi pergumulan dapat dibagikan menjadi pelajaran anggota komsel lainnya. ${ }^{38}$ Dengan demikian, bahan yang dipelajari bukan saja hanya bahan yang sudah disiapkan oleh gereja baik dalam bentuk buku, modul dan warta. Bahan yang patut dipelajari dalam komsel harus juga mempercakapkan kesaksian atau pengalaman jemaat dalam kehidupan sehari-hari berjalan bersama Allah.

\section{KESIMPULAN}

Pada abad kedua puluh ini, fenomena pelayanan komsel semakin berkembang dan semakin digalakkan oleh gereja-gereja. Komsel sendiri merupakan salah satu pelayanan ujung tombak dalam memuridkan anggota jemaat dan sarana untuk menjangkau jiwa. Secara praktis dalam pelayanan komsel ada beberapa kegiatan penting yang harus dilaksanakan yakni doa, pujian, penyembahan serta pengajaran. Sehubungan dalam komsel ada pengajaran maka gereja wajib menyiapkan bahan ajar yang relevan dengan kebutuhan anggota komsel. Hal ini penting untuk membuat anggota komsel tertarik untuk mengikuti kegiatan komsel dan membuat mereka semakin dewasa dan bertumbuh dalam pengenalan akan Tuhan, serta mampu menjawab tantangan hidup yang sedang mereka hadapi. Untuk membuat bahan ajar komsel yang relevan dengan kebutuhan anggota komsel, maka ada beberapa aspek yang penting untuk diperhatikan, yaitu: bahan ajar komsel harus mudah dimengerti oleh anggota komsel, bahan ajar komsel juga harus sesuai dengan tingkat kerohanian anggota komsel. Selanjutnya, bahan ajar komsel harus berfokus kepada Alkitab dan tematema pokok dalam Alkitab. Materi komsel harus ditinjau dari sudut Perjanjian Lama maupun Perjanjian Baru. Selain itu, bahan ajar komsel harus sesuai dengan tingkat psikologi anggota komsel. Berbeda tingkat usia dan perkembangan maka berbeda pula tantangan hidup yang dihadapi oleh anggota komsel. Berikutnya, bahan ajar dalam komsel harus mampu menjawab pergumulan hidup yang sedang dihadapi oleh anggota komsel. Aspek terakhir yang penting untuk dipertimbangkan adalah pengalaman hidup anggota komsel bersama dengan Tuhan dapat dijadikan menjadi 
bahan ajar dalam komsel untuk menjadi kesaksian hidup dalam rangka memotivasi anggota komsel lainnya yang sedang menghadapi pergumulan hidup.

\section{DAFTAR PUSTAKA}

Barker, Steve, Judy Jhonson, Jimmy Long, Rob Malone, and Ron Nicholas.

Pemimpin Kelompok Kecil. Jakarta: PERKANTAS, 1996.

Chapman, Adina. Pengantar Perjanjian

Baru. Bandung: Kalam Hidup, 2019.

Darmadi, Daud. "Makna Kolose 2:6-7

Dalam Pertumbuhan Rohani Jemaat Masa Kini" 1, no. 2 (2019): 26.

Donahue, Bill. Membimbing Kelompok Kecil Untuk Mengubah Hidup. Yogyakarta: Gloria Graffa, 2010.

Drane, John William, and P. G Katoppo. Memahami Perjanjian Baru: pengantar historis-teologis, 1996.

Eausum, Bill, and Jhon Atkinson. 11 Langkah Meledakkan Kelompok Sel. Surabaya: Gandum Mas, 2016.

Echols, and Hasan Shadily. Kamus Inggris - Indonesia. Jakarta: PT. Gramedia, 1996.

Evimalinda, Rita. "Konsep Kurikulum Pembinaan Warga Gereja Khususnya Remaja." REAL DIDACHE. Jurnal STT REAL BATAM 3 No 1 (2018).

Garisson, Alton. Pemuridan Yang Berhasil: Murid 360. Surabaya: Gandum Mas, 2016.

Gladen, Steve. Memimpin Kelompok Kecil Dengan Tujuan. Yogyakarta: Yayasan Gloria, 2015.

Hanson, Tjung. "Kenapa Harus Komsel?" Accessed August 14, 2021. https://hansontjung.com/2018/09/1 3/kenapa-harus-komsel/.

Hasugian, Johanes Waldes. "Kurikulum dan Pembelajaran Warga Jemaat Dewasa di Gereja" (2019): 18.

Ismail, Andar. Selamat Sejahtera: 33 Renungan Tentang Kedamaian. Jakarta: BPK Gunung Mulia, 2002.

Marbun, Purim. "Strategi dan Model Pembinaan Rohani untuk Pendewasaan Iman Jemaat.” Jurnal Ilmiah Religiosity Entity Humanity (JIREH) 2, no. 2 (December 23, 2020): 151-169.

Neighbour, Ralph W. Where Do We Go from Here?: A Guidebook for the Cell Group Church. Houston, Tex.: Touch Publications, 2000.

Pazmiño, Robert W. Foundational Issues in Christian Education: An Introduction in Evangelical Perspective. Grand Rapids, Mich: Baker Book House, 1988.

Samuel Hakh, Benyamin. Perjanjian Baru. (Bandung: Bina Media Informasi, 2010.

Sidjabat, B.S. Mengajar Secara Profesional. 3rd ed. Bandung: Kalam Hidup, 2017.

. Pendewasaan Manusia Dewasa. Bandung: Kalam Hidup, 2014.

Simanjuntak, Ika Widyasari, and Talizaro Tafonao. "Urgenitas Dalam Menerapkan Kurikulum Pendidikan Agama Kristen Bagi Orang Dewasa Di Gereja" 1 (2021): 16.

Sonny, Eli Zaluchu. "Strategi Penelitian Kualitatif Dan Kuantitatif Di Dalam Penelitian Agama." StrategiPenelitian Kualitatif dan Kuantitatif di dalam Penelitian Agama", Evangelikal: Jurnal TeologiInjili dan Pembinaan Warga Jemaat 1 (2020): 28-38.

Stepanus, "Keunggulan Yesus Kristus 
Menurut Kolose 1:16-18." HUPERETES: Jurnal Teologi dan

Pendidikan Kristen 1, no. 1

(December 14, 2019): 49-61.

Subandrijo, Bambang. Perjanjian Baru 1.

Bandung: Bina Media Informasi, 2010.

Sugicahyono, Joni. "PANDUAN

KELOMPOK KECIL.” Adoc.Pub.

Accessed August 14, 2021.

https://adoc.pub/panduan-

kelompok-kecil-sub-bidang-

pembinaan-warga-gereja-sin.html.

Sutoyo, Daniel. "Komunitas Kelompok

Kecil Sebagai Tempat

Pembelajaran Gaya Hidup

Kristen." Jurnal Antusias, STT.

Intheos 2, No 2 (2012).

Tanya, Eli. Gereja Dan Pendidikan Agama

Kristen: Mencermati Peranan

Pedagogis Gereja. Cipanas:

Sekolah Tinggi Teologi Cipanas, 2006.

Tim Staf Perkantas. Pemuridan dinamis membangun bangsa: memuridkan berbasis kelompok kecil dan profil, 2013.

Widjaja, Imron. "Perkembangan Komsel Pelajar Dalam Pertumbuhan Rohani Jemaat GBI GRAHA PENA JAKARTA” 5, no. 2 (2019). 
36 | SANCTUM DOMINE: Jurnal Teologi, vol. 11, no. 1 (2021) 